\title{
Suggestions for Prospecting
}

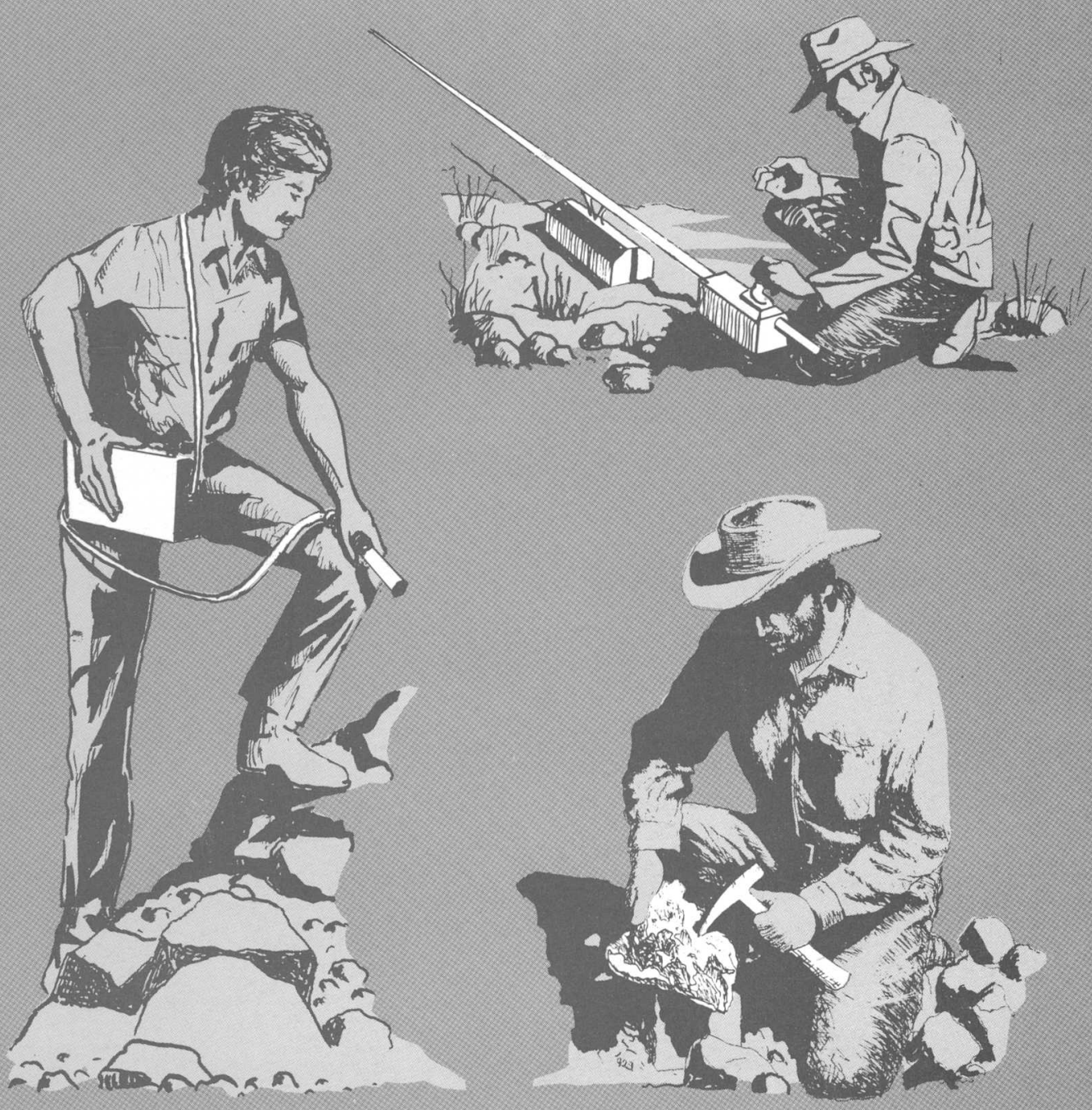





\section{Suggestions for Prospecting}
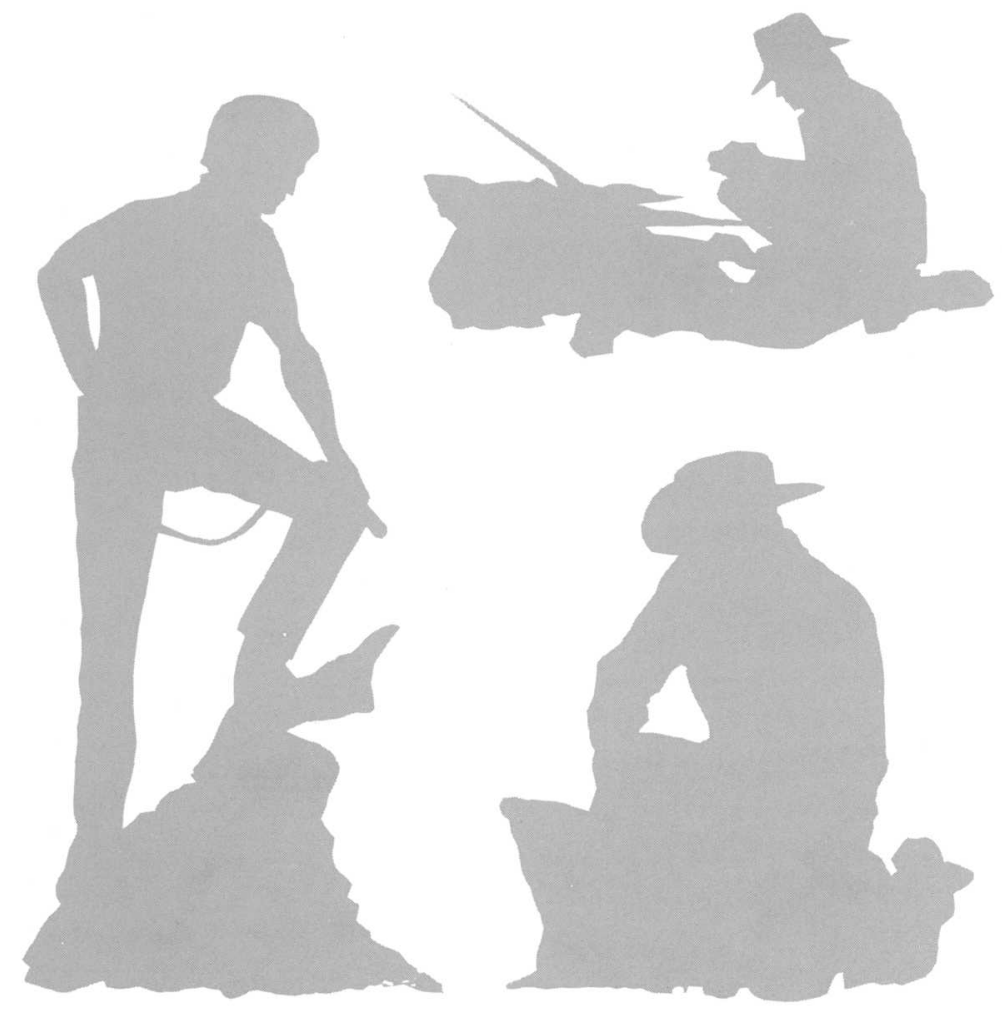

For sale by the Superintendent of Documents, U.S. Government Printing Office Washington, D.C. 20402 


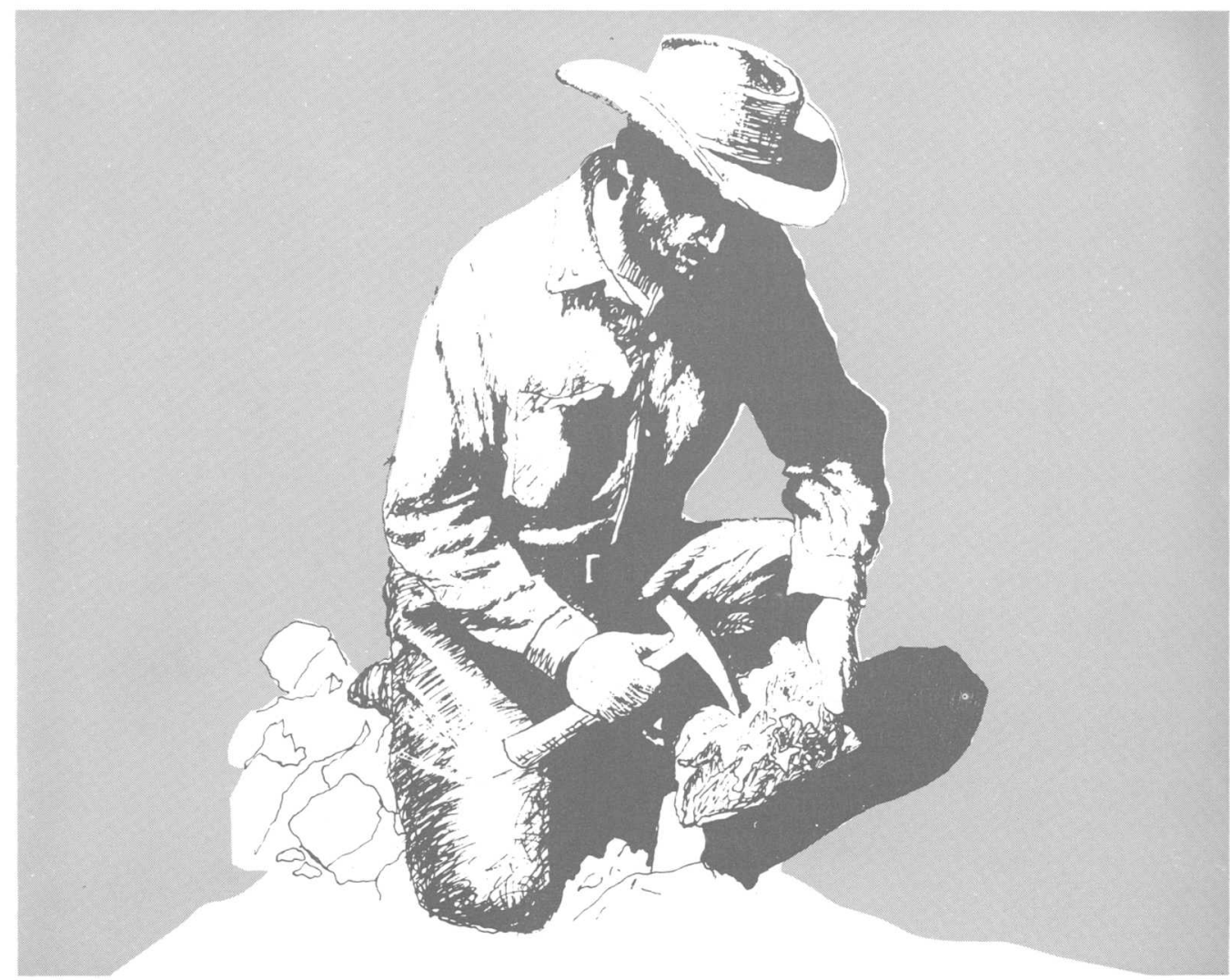

Prospectors have contributed much to the development of this Nation's mineral resources. Since the time of the earliest settlement, the need for iron for tools and guns, lead for bullets, and copper for utensils has prompted a search for sources of these metals. The lure of gold and silver provided the impetus for much of the development in the West between 1850 and 1910. Later, prospectors carried out successful ventures to fulfill the country's expanding industrial demands for other metals such as zinc, molybdenum, tungsten, chromium, vanadium, and many others. Even America's uninhabited rugged mountains or barren deserts have been prospected although perhaps only at a reconnaissance scale.

Nearly one billion tons of surface and underground material are mined annually in the United States to recover about one-half billion tons of metallic ores, principally iron and copper (U.S. Bureau of Mines' "Minerals Yearbook, 1986," 1988, v. 1, p. 25). Even greater amounts of ore must be found in the future to meet the Nation's increasing needs and to replace exhausted deposits. The easily found deposits have already been discovered; success in finding new deposits will depend more and more on modern prospecting techniques. 
Prospecting 『echni̊nues

The modern prospector has advantages that to some extent make up for the increased difficulty of finding ore deposits. One advantage is greatly increased knowledge about the geologic factors that localize ore deposition. The search for new deposits has become a complex undertaking, and the prospector should be as well-informed as possible. The prospector should acquire the ability to identify not only ore minerals but also common rocks and their minerals, as well as many kinds of geologic structures. This knowledge is best acquired by academic training, but much can be learned from studying reference books such as "Exploration and Mining Geology" (Peters, 1987), "Handbook for Prospectors" (Pearl, 1973), and others listed at the end of this booklet.

The first technique used in a prospecting venture is geological inference. The prospector studies reports, geologic maps, and cross sections of a region to pinpoint areas where there are structures, rocks, and minerals with which ores are usually associated. These areas warrant further exploration. Topographic maps or aerial photographs of these targeted areas are obtained and used in plotting information, such as locations for sampling. This booklet briefly describes basic prospecting techniques-geochemical, geophysical, and combination methods - that can help lead to the discovery of an orebody. An orebody, as defined by the U.S. Bureau of Mines' "Dictionary of
Mining, Mineral, and Related Terms"' (Thrush and others, 1968), is "a mineral deposit that can be worked at a profit under existing economic conditions."

Remoie Sensing is a relatively new method of mineral exploration, utilizing imagery of the Earth's surface collected by instruments on aircraft and Earth-orbiting satellites. Imagery of radar, color infrared, thermal infrared, and other reflected or radiated electromagnetic energy, can show features such as structure, vegetation, and rock types that may not be discernable by conventional ground-based prospecting methods.

Prospecting equipment can be used in many ways, according to the minerals sought and the methods employed in the search. Its effectiveness depends in large measure on the operator's awareness of its applications. For example, radiation counters (the scintillometer, for example) not only detect radioactive minerals for the uranium prospector, but can also be useful to placer prospectors. Some placer deposits contain both gold and heavy radioactive minerals such as monazite; the radiation counter points out gold concentrations by detecting the associated monazite. A "black light" (ultraviolet lamp), commonly used in prospecting for fluorescent ore minerals such as scheelite (a tungsten ore), is also useful in detecting fluorescent rock-forming minerals such as calcite, barite, or fluorite, which can be indicators of associated metallic minerals. 


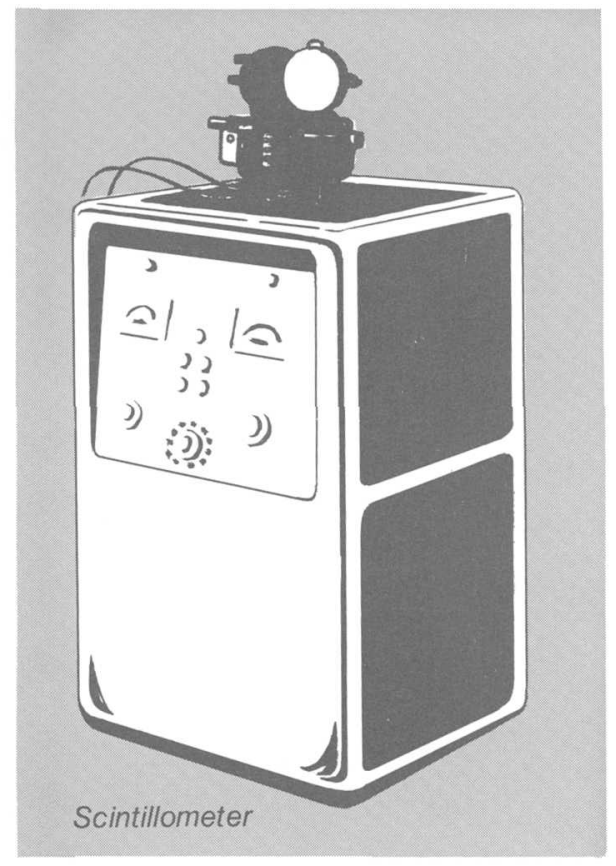

The residues left in rocks after ore minerals have been removed by weathering also may be clues to ore deposits. The rusting of iron is a familiar example of the change in materials exposed to weathering. Primary ore minerals (that is, minerals deposited in the rock formation by ascending ore-forming solutions) near the surface may be oxidized and carried in solution downward from their original position. They may be either redeposited as secondary minerals in the rocks below, thus enriching lower parts of the mineral deposit; or the minerals may be dissolved and completely removed, resulting in a process of depletion rather than enrichment.

Regardless of what happens to the ore minerals during weathering, some evidence of their former presence remains. Commonly, iron oxides and iron hydroxides form and remain as brown or yellow stains and encrustations on the surface rocks. The solution of minerals can result in a sponge-like, ironstained, porous rock called gossan-evidence that primary minerals have been oxidized and at least partly removed. A search for these minerals at depth in such places may be fruitful. Mineral compounds containing copper, nickel, cobalt, molybdenum, uranium, and other metals may oxidize to form brightly-colored secondary minerals on the surface rocks. These minerals are found mainly in dry regions because many of them are soluble in water and would be leached away in areas of heavy rainfall.

Mineral deposits have also been located by following float (pieces of rock found on the ground surface) uphill to its source. When rocks are being eroded, fragments are carried downhill by gravity and downstream by water. The source of the float can be found by tracing the pieces up slope.

The systematic panning of stream sediment and residual soil for gold or other resistant heavy minerals has long been used to find bedrock lodes. The gold pan, an indispensable prospecting tool, is versatile, efficient, inexpensive and portable. From a sample, an experienced panner can recover 80 percent of the minerals that are heavier than quartz (specific gravity 2.65). Even an inexperienced person can obtain a concentrate of heavy minerals from an ore-bearing sample that will 
contain virtually all of the sample's coarse gold and platinum, and a high percentage of its magnetite (specific gravity 5.2) and heavier minerals such as cassiterite, cerussite, coulumbite-tantalite, scheelite, and silver. Many minerals such as hornblende, biotite, muscovite, epidote, garnet, pyrite, cinnabar, and galena are easily recognized during the washing process, and the skillful panner can recover most of these minerals present in a sample. A sample that is "panned down" to "black sands", generally also contains a number of light-colored heavy minerals such as barite, zircon, sphene, monazite, and scheelite, in addition to the darker minerals such as magnetite, ilmenite, hematite, and sulfides. All these minerals can be clues to valuable deposits in nearby or upstream areas.

Other devices can be used in conjunction with a gold pan to test large samples; dozens of varieties of sluiceboxes, rockers, suction devices, and spiral concentrators are available from prospecting and mining equipment dealers. An inexpensive portable sluicebox for use in sampling placer deposits can be made from three pieces of $1 / 8$-inch

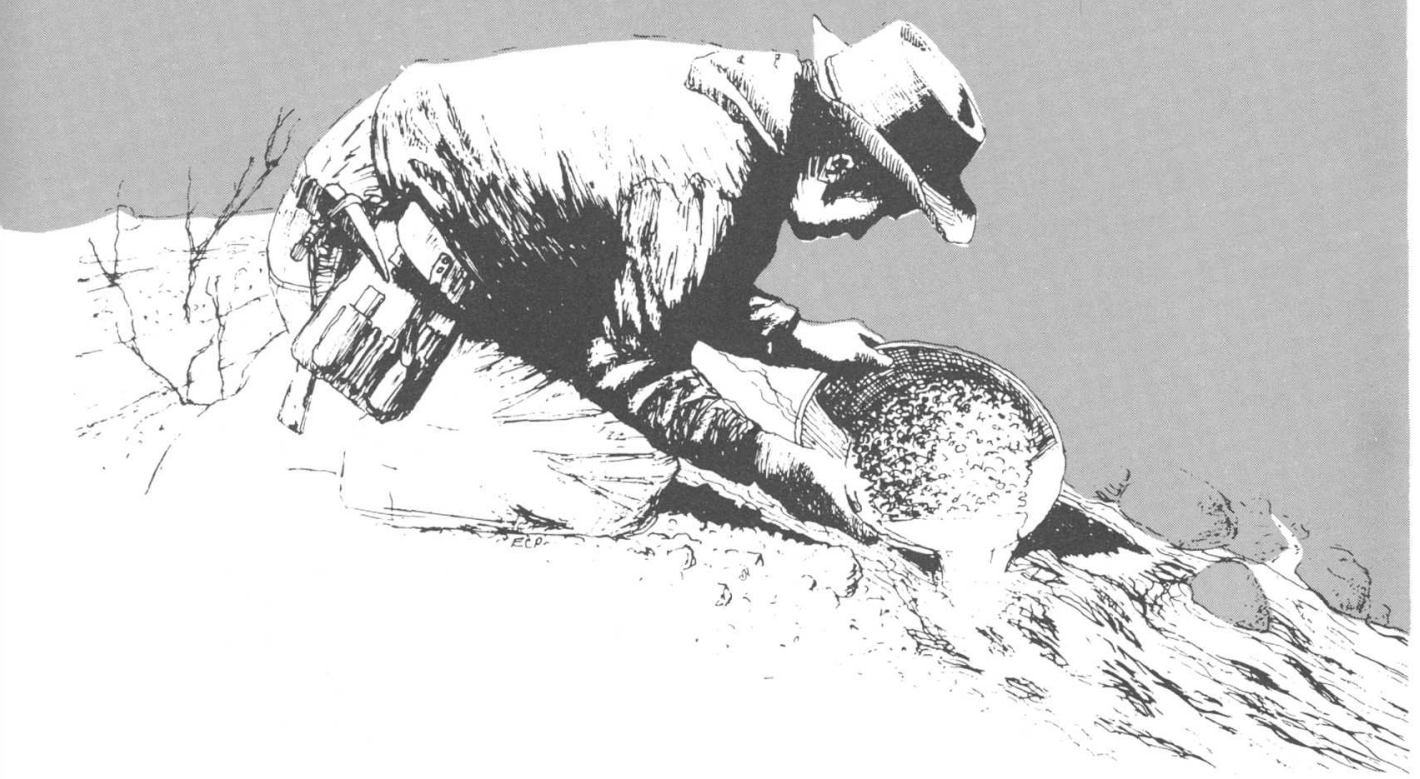


sheet aluminum, each 3 feet long and about 1 1/2 feet wide. The metal is shaped into flat-bottomed troughs about 1 foot wide with sides 3 inches high; the three sections are bolted end-to-end to form a 9-foot sluice. The bottom of the sluice box is fitted with carpet, burlap, wooden cross-slats or riffles, or other material to trap fine heavy mineral particles. Covering the material with a coarse screen prevents pebbles from clogging the trapping material. Water is delivered to the sluicebox by means of a pump driven by a small gasoline engine, or the sluicebox can be placed in the stream to use the natural flow of water. The bottom end of the sluicebox should be partly closed to slow down the water flow and to aid in trapping heavier particles. The carpet or burlap containing the heavy mineral concentrate is removed from time to time, placed in a tub, and thoroughly washed. The washings are then further concentrated by panning. Working diligently, one can wash a ton of gravel in a day and expect to recover 50 percent or more of the black sands present.

Many mineral deposits are not exposed at the Earth's surface. They may be concealed by thick soil cover or may lie buried beneath layers of rock. To find them, more complex techniques-based on geochemistry, geophysics, and geobotany-can be very helpful. Most of these techniques require specialized training, and, in some instances, expensive equipment. These techniques are described below.

\section{Geochemical Prospecting}

Geochemical prospecting is based on systematic measurement of chemical properties of rock, soil, glacial debris, stream sediment, water, or plants. The chemical property most commonly measured is the content of a key trace element. Zones in the soils or rocks of comparatively high, or anomalous, concentrations of particular elements may guide the prospector to the elements in rocks or soils that constitute a geochemical anomaly (different from normal). The actual amount of the key element in a sample may be very small and yet constitute an anomaly if the sample's concentration is high relative to the concentration of the surrounding area. For example, if most samples of soil are found to contain about 0.00001 percent $(0.1$ parts per million, or $p p m$ ) silver, but a few contain as much as 0.0001 percent (1 ppm), the few "high" concentrations are geochemical anomalies. Plots of analytical results on a map may indicate zones to be explored further.

Geochemical anomalies are classified as primary or secondary. Primary anomalies result from outward dispersion of elements by mineral-forming solutions. High concentrations of metals surround the deposit, and the dispersion of metals laterally or vertically along fractures or faults may result in a "halo" surrounding the deposit. Halos are especially useful in prospecting because they may be hundreds of times larger than the deposit they surround and hence are easy to locate. 


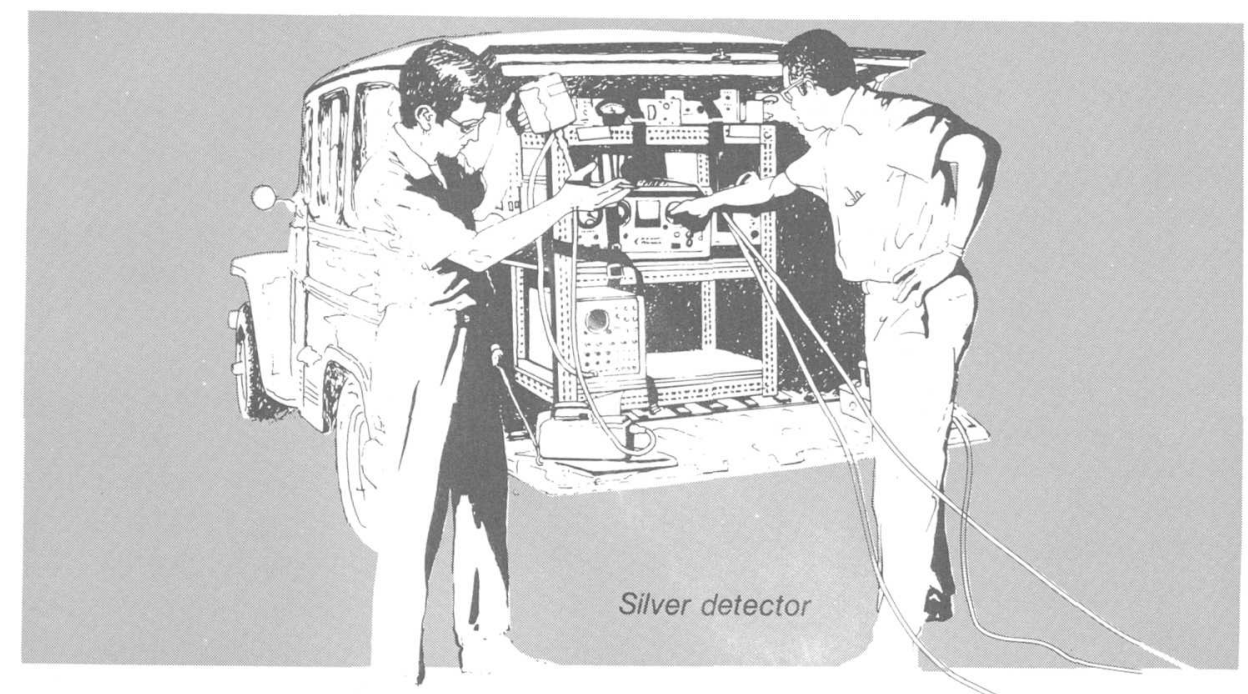

Secondary anomalies result from dispersion of elements by weathering. Some primary minerals, such as gold or cassiterite, are resistant to chemical weathering and are transported by the streams as fragmental material. Other primary minerals may be dissolved and the metals may be either redeposited locally or carried away in solution in ground and surface waters. Some metals in solution are taken up by plants and trees and can be concentrated in their tissues. Many studies have been made of the metal content of residual soils over sulfide deposits, and in general the distribution of anomalous amounts of metal in the soil has been found to correspond closely with the greatost concentration of metals in the underlying rock.

Most products of weathering in a drainage basin enter the streams and rivers that flow across it. The weathered products occur as chemicals in solution in the streams' water and in their sediments. Either or both can be sampled and tested, and composition of the samples will reflect the chemical nature of the rocks in the drainage basin. The presence of ore may be determined by sampling water and sediment from each successive tributary and by analyzing the samples for anomalous amounts of metals. This procedure narrows the search for ore deposits to the most favorable areas.

Contamination of surficial material by human activity is an ever-present hazard in geochemical surveys. The most common sources of contamination are materials derived from mine workings. Similarly, smelter fumes, wind-blown flue dust, and metallic objects may also contaminate the soils and rocks. Such materials may oxidize and go into solution, contaminating the soil, stream sediment, and water nearby, thus masking natural anomalies.

Analytical methods used in geochemical prospecting must be sensitive enough to determine 
minute amounts of key elements, accurate enough to show small differences in concentration, fast enough to permit large numbers of samples to be analyzed in a day, and inexpensive. Wet chemical techniques are usually confined to rapid colorimetric procedures that require a minimum of equipment and materials. Instrument techniques, such as emission spectrographic and X-ray fluorescence, require expensive equipment and trained personnel, but usually yield a lower cost per determination if thousands of samples must be analyzed.

Wet chemical methods.

Analytical techniques for many elements have been devised for use in geochemical prospecting. These range from very simple procedures that can be accomplished in the field, through less simple procedures that can be carried out in an improvised laboratory at a campsite, to complex procedures that require a well-equipped laboratory.

Simple procedures to test for heavy metals, as well as campsite tests mostly requiring heating and leaching, are described in U.S. Geological Survey Bulletin 1152 (Ward and others, 1963). Their precision is adequate for prospecting, and the costs are not high. Commercial kits for some of these tests are available starting at reasonable cost; they are advertised in most popular mining journals.

U.S. Geological Survey Circular 948 (O'Leary and Meier, 1986) describes methods for determination of gold, calcium, indium, lithium, magnesium, potassium, sodium, tellurium, thallium, tin, tungsten, and uranium; U.S. Geological Survey Bulletin 1408 (Ward, F.W., ed., 1975) discusses methods for testing for antimony, arsenic, bismuth, cadmium, cobalt, copper, fluorine, lead, mercury, molybdenum, nickel, selenium, silver, and zinc.

More sophisticated methods of analysis, particularly those employing hazardous chemical or complicated procedures, are best done in an established laboratory. Laboratory methods usually permit about the same productivity as the campsite methods but require a trained chemist to perform them correctly.

Instrument techniques. The types of instruments used mostly for large-scale prospecting are emission spectrographs, atomic absorption spectrophotometers, and X-ray spectrographs because they permit quick identification of most elements. Instrument techniques are described in detail in U.S.

Geological Survey Bulletin 1770A-K (Baedecker, 1987) and in U.S. Geological Survey Circular 948 (O'Leary and Meier, 1986).

Emission spectrographic methods have been widely used and have the distinct advantage of giving results for 40 to 60 elements or more in each sample. To accomplish the analysis, heat of an electric arc or spark vaporizes a sample, which excites the atoms of the elements in the sample so that they emit light. A prism or diffraction grating disperses this light into a spectrum containing lines of definite wavelengths that are characteristic for various elements. 
From the intensity of these lines, as recorded photographically or electronically, the concentrations of sought-after elements in the sample may be determined. Many commercial laboratories offering spectrographic analyses are advertised in mining journals.

Atomic absorption is the opposite of emission spectrography, in that atom vapors in an unexcited state will absorb the light that they characteristically give off in an excited state. This phenomenon is used in mercury detectors. The interest in mercury is twofold. Not only a valuable metal in itself, mercury also occurs in small quantities with many different ores, such as those of silver, gold, lead, zinc, and copper. The presence of mercury, therefore, may indicate the presence of these other metals. Further, mercury is a volatile element and is transported as a gas that easily diffuses through small fractures and porous rock. Thus, a mercury halo presents a larger target for the prospector than halos produced by many other elements.

In X-ray spectrography (sometimes called $X$-ray fluorescence spectrography), bombardment with $\mathrm{X}$-rays excites the atoms in solid samples that then release their acquired energy in a radiation spectrum characteristic of each element. An X-ray spectrograph is an instrument designed to use this property for determining the concentrations of elements in a sample. It requires high voltages and adequate radiation shielding to protect the operator. X-ray analyses can be obtained from many commercial laboratories.

Biological prospecting. Plants, humus, and bacteria have been successfully used as aids in mineral prospecting, and under certain conditions they may assist the prospector in locating buried mineral deposits. So many factors are involved, however, that it is not possi-. ble to predict conditions under which biological prospecting will be

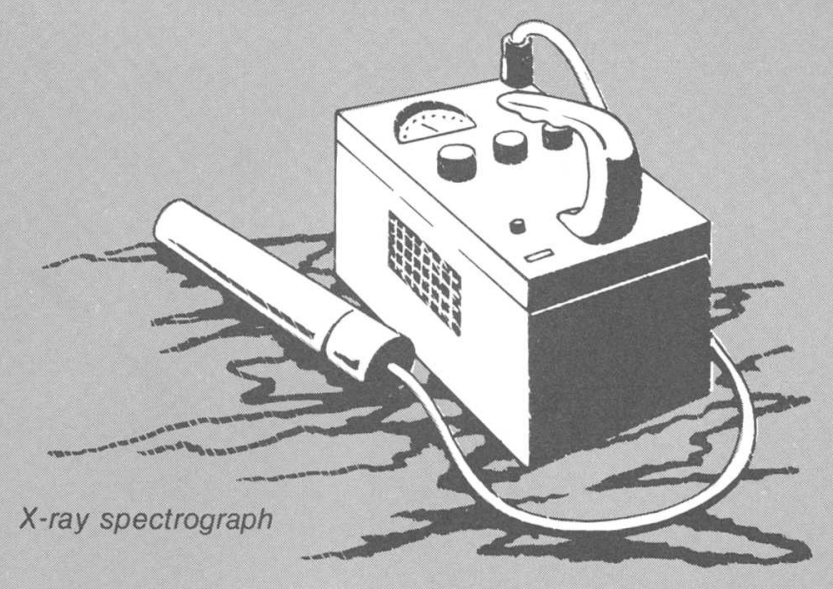


helpful. However, biological prospecting can be a valuable adjunct to conventional prospecting methods.

Many plants, by means of their extensive root systems and the absorptive ability of their roots, effectively sample many of the elements that are within reach and transfer these elements to the branches, stems, and leaves, which can be chemically analyzed. Thus, under ideal conditions, the plant has sampled the underlying soil or rock in its root zone to depths of as much as 50 feet. The advantages to the prospector of being able to sample plants and thus to obtain information about the metals that occur at considerable depth are obvious, although problems in interpreting this information may render this method of prospecting impractical under many field conditions. For instance, some plants, because of their genetic makeup, selectively concentrate elements in their roots, stems, or leaves in higher concentrations than are found in the underlying soil and rocks. Whenever possible, soil and rock samples should also be analyzed before concluding that a geobotanical anomaly indicates the presence of certain minerals in an area.

Forest humus also has been successfully used to locate mineralized rock, especially where it is hidden by soil. Elements are immobilized and concentrated in the humus layer as twigs, leaves, and other parts of the forest vegetation fall to the ground and decay. Studies in the United States, Canada, Scan- dinavia, and the Soviet Union have shown that chemical analysis of forest humus yields results which delineate zones of gold and other metals much more accurately than results from the underlying soil (Curtin and others, 1971.)

For a review of the use of geobotany and biogeochemistry in mineral exploration, see "Biological Methods of Prospecting for Minerals" (Brooks, 1983), "The Use of Plants in Prospecting for Precious Metals, Principally GoldA Selected Reference List and Topic Index" (Erdman and Olson, 1985), and "Mineral ExplorationBiological Systems and Organic Matter" (Carlisle and others, 1986).

\section{Geophysical Prospecting}

Geophysical prospecting combines the sciences of physics and geology to assist the prospector in exploring for both mineral and energy fuel deposits. Familiar examples include the use of scintillation counters for detecting radioactive uranium deposits and magnetic surveys for locating iron deposits.

Five major geophysical methodsmagnetic, gravimetric, geoelectric, radiometric, and seismic-are routinely used in mineral exploration. Application of some of these methods and techniques requires complex and costly instruments and sophisticated methods of processing and interpreting the data, but others are relatively simple and inexpensive. Among the latter are the magnetic and radiometric methods 
and some of the geoelectric techniques, which are outlined here.

Magnetic methods. Magnetic prospecting is based on the natural magnetic properties of some minerals such as magnetite. When held near a magnetite-rich rock, the needle in a compass behaves erratically because the Earth's magnetic field is distorted by the magnetic field of the rock. Rocks containing minerals such as magnetite (iron oxide), and pyrrhotite (iron sulfide) are usually magnetic enough to be recorded by sensitive magnetic instruments.

The common unit of measure for the strength of a magnetic field is the gamma. Where not disturbed by highly magnetic rocks, the strength of the Earth's magnetic field in the conterminous United States ranges from a low of about 48,000 gammas in Texas and Florida to a high of about 60,000 gammas in Minnesota.

Instruments called magnetometers are used for direct detection of magnetic anomalies (that is, the distortion of the Earth's magnetic field by magnetic minerals in crustal rocks). The magnetic readings over weakly magnetic rocks may depart from local average (background) values by 10 to 500 gammas, but over magnetic iron formation the readings may depart from background by 100 to 100,000 gammas. The magnetometer can be used to trace concealed rock formations that have magnetic properties differing from those of adjacent formations. It can also be used indirectly in the search for ore minerals. For example, the "black sand" of

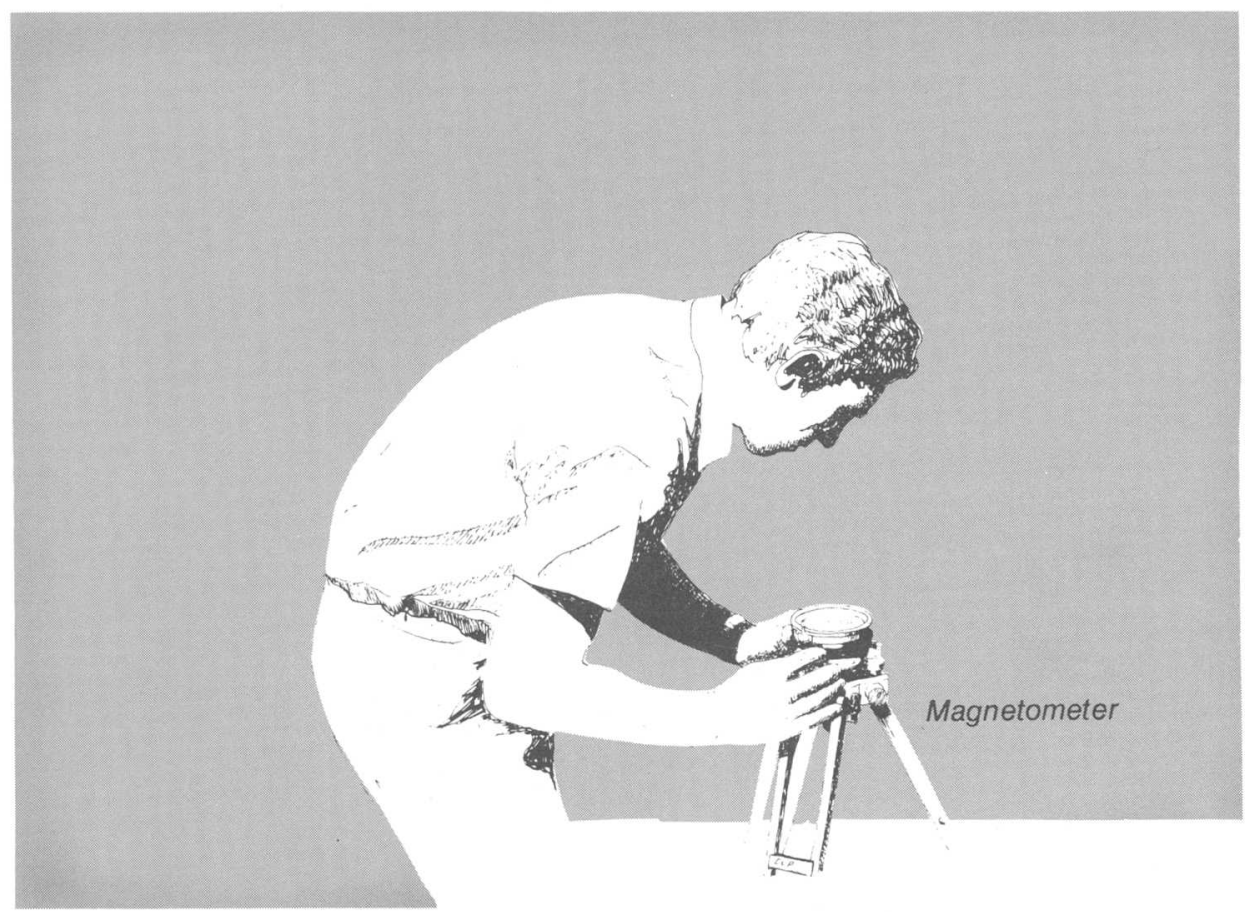


placer deposits commonly contain grains of magnetite that affect the magnetometer. Thus, it can be used in the search for gold or other heavy minerals present in the black sand.

Two commonly used magnetometers are the fluxgate and the proton. A fluxgate is an electronic device that measures the strength of the field in a particular direction. The proton magnetometer's sensing element is a container filled with a proton-rich liquid such as water or kerosene surrounded by a coil of wire; protons are subatomic particles that spin about rotational axes. The frequency with which the spin axes of the protons wobble, or "precess,". after being aligned by a strong current passed through the coil, is directly related to the strength of the Earth's field. This frequency is measured and converted into readings in units of gammas. The proton magnetometer measures the total intensity of the Earth's field rather than the intensity in a vertical or horizontal direction.

Magnetic surveys may be conducted either along a series of lines or in a grid pattern. The size of the area being prospected and the type of deposit being sought determine the spacing of stations. Stations spaced 10 to 20 feet (approximately 3 to 6 meters) apart may be required to locate small magnetic anomalies associated with weak or moderately magnetic rocks, but stations spaced 100 feet (approximately 30 meters) or more apart may suffice if the presence of highly magnetic rocks is suspected in a large area. Powerlines, rails, automobiles, and other large metallic objects should be avoided in any type of magnetometer survey because they create strong local magnetic fields that mask the anomalies inherent in the rocks.

Today most magnetic surveys are airborne or marine and use totalfield detecting systems and vertical gradient systems. Instruments called vertical gradiometers measure the vertical magnetic gradient; this helps to locate the edges of magnetic zones, rock units, and other geologic features. These surveys provide comprehensive reliable data about regional magnetic trends. Ground magnetometer surveys are still used to locate anomalies from small subsurface structures.

Geoelectric methods. Most electrical prospecting is based on the fact that various minerals and rocks offer differing degrees of resistance to the flow of electric current. Electrical resistivity of rocks, measured in ohm-meters, can vary from several thousand ohm-meters for some igneous and metamorphic rocks to a few ohm-meters for shales and clays. Some orebodies have such low resistivity that geophysicists refer to them as conductors (conductivity is the inverse of resistivity). For example, the resistivity of most common sulfide minerals, such as chalcopyrite (copper-iron sulfide) and galena (lead sulfide), but not including sphalerite (zinc sulfide), is very low-a fraction of an ohmmeter. If the individual grains in a sulfide orebody are in good electrical contact with each other, the entire orebody may offer a very low 
resistance to the flow of electricity compared to the surrounding rocks, and hence be called a conductor. Other bodies, such as clay pockets, graphite schists or sediments saturated with brine can also be good conductors.

Many electrical techniques are used in searching for conductors that may be orebodies. Some require very expensive and complicated instruments and large field crews to make the measurements, and mathematical computations must be applied to the data before interpretation. Other techniques, however, use only moderately expensive equipment that is easily operated by one or two persons and require little or no use of mathematics. For example, the VLF method employs very low frequency (VLF) radio signals, electromagnetic fields transmitted from a number of powerful stations around the world that continuously broadcast in the range of $15-25 \mathrm{kHz}$. The primary fields from these stations penetrate the Earth to depths of 30-300 feet (approximately 10-100 meters) and cause electrical currents of the same frequency to flow in the Earth. This current creates secondary magnetic fields that can be detected at the Earth's surface. In areas where the electrical resistivity of the Earth is uniform, the primary and secondary fields at the surface are also uniform and are oriented in the horizontal direction. Where the resistivity of the Earth is not uniform, however, the currents tend to concentrate along low resistance paths such as may be provided by orebodies. This causes disturbances in the secondary fields at the surface that can be measured and used to predict the presence and location of orebodies.

The basic measuring instruments in the VLF method consist of one or more induction coils, which are used to sense the VLF magnetic field, a VLF radio receiver, and a readout device. In some instruments the tilt of the VLF magnetic field from the horizontal plane is measured; in other instruments its amplitiude in the horizontal direction is measured. Measurements are made along lines or a grid in the same manner that magnetic surveys are conducted. Ordinarily a station spacing of 25 to 50 feet (approximately 5 to 15 meters) is adequate. Powerlines, pipelines, metal fences and other large metallic objects, even if they are not steel, should be avoided because they act as conductors and cause anomalous fields not related to orebodies.

Another technique, the Slingram electromagnetic method, uses a local transmitter consisting of a battery powered source of alternating current and an air- or metal-cored induction coil that serves as the antenna. The operating frequencies range from about $200 \mathrm{~Hz}$ to 4,000 $\mathrm{Hz}$. The separation between the transmitter and the receiver varies from about 100 to 800 feet (approximately 30 to 240 meters). The receiver for this technique measures the in-phase and the out-ofphase portion of the received signal, that is, the amount of secondary field that aligns with the broadcast field and the amount that is perfectly misaligned with it. The 
presence of a low-resistivity orebody distorts the fields that are observed at the surface. In general this technique has a greater depth range than the VLF method and often provides data that are easier to interpret than data from the VLF method. Disadvantages are that two persons are needed to make measurements and that survey lines must be cleared and measured in advance to work in wooded terrain.

Another group of electromagnetic devices, metal detectors, are small portable instruments consisting of a wire loop suspended above the ground along which an alternating current flows, inducing currents underground. The secondary magnetic fields thus created can be measured by audible signals. Metal objects below the ground surface (at depths of a few feet) distort these fields, creating a change in the frequency of the audible signal.

Electromagnetic techniques respond to the presence of rocks bearing significant quantities of sulfides, graphite, or clays, to waterfilled shear zones, and to overburden, particularly when clays or saline waters are present. Where geologic evidence indicates the possible presence of an orebody, magnetometer measurements may help discern anomalies likely to represent valuable mineral deposits.

Electrochemical methods are used as a follow-up to the abovementioned methods. An orebody that is actively being oxidized can act as a natural battery, causing the surface of the Earth above it to have an electrical potential that is different from the surrounding area.
In the self-potential method, two nonpolarizing electrodes placed on the surface of the Earth are connected to a sensitive millivoltmeter, and the difference in potential is measured. Ideally, one electrode is left in a fixed position, and the other electrode is moved along lines or a grid to measure the variations in self potential. No calculations are necessary unless more than one location is used for the fixed electrode. Sources other than mineral deposits also have variations in self potential. Thus, results from this method should be correlated with other geologic evidence to indicate the presence of an orebody.

Radiometric methods. Naturally occurring radioactive elements such as potassium, uranium, and thorium decay to other elements or isotopes by emission of subatomic particles. Gamma rays (similar to X-rays, but higher in frequency), alpha particles (nuclei of helium atoms), and beta particles (electrons) are most commonly emitted during this process.

Radiation counters (Geiger counters, scintillometers, and gamma ray spectrometers) detect differences in intensities of radioactivity and are used in finding deposits of radioactive minerals. The Geiger counter is a tube filled with a gas such as helium, argon, or krypton. A highvoltage wire extends into the central part of the tube. When gamma radiation or beta particles pass into the tube from a radioactive source, some of the rays collide with gas molecules and produce electrically charged particles that are then attracted to the central wire and produce electrical pulses. The elec- 


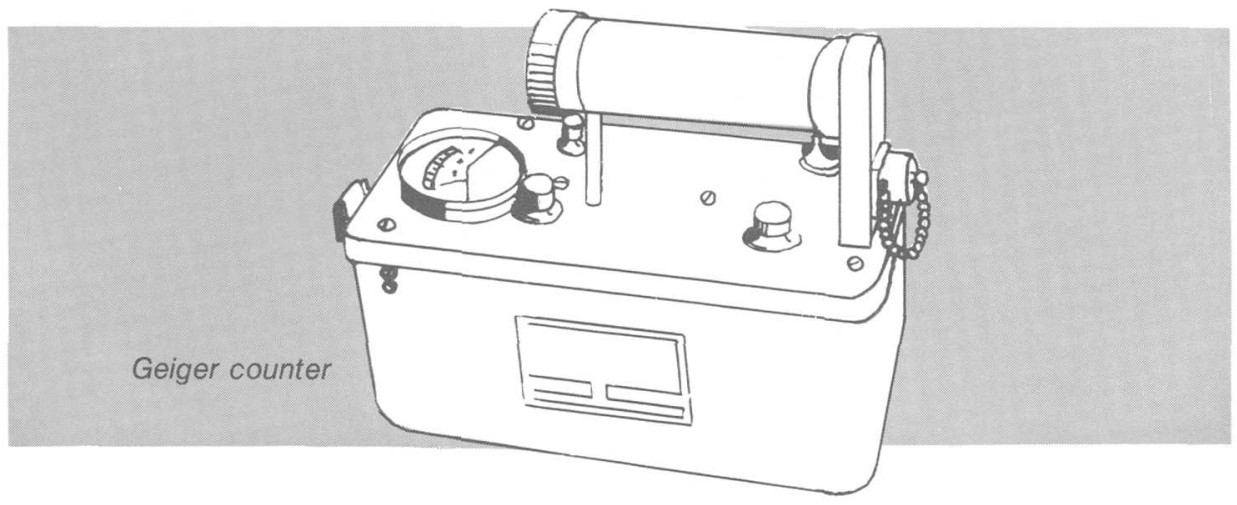

trical pulses can be translated into dial readings of counts per minute. Scintillometers use crystals of certain compounds, such as sodium iodide, which emit flashes of light when struck by radiation. A photoelectric cell "sees" the flash of light or scintillation and electronically counts the numbers of flashes per unit of time. This can be transmitted to a dial reading in counts per minute. Scintillometers are more sensitive than Geiger counters; Geiger counters are no longer widely used, as they lack the necessary sensitivity to find lowergrade ("lean") deposits. While sensitive to very small differences in amounts of radioactive elements in rocks, Geiger counters and scintillometers do not show what element produces the radioactivity; such distinctions are made by chemical analysis of the radioactive rock. The gamma ray spectrometer will give ppm levels of thorium, and uranium, or the percent of potassium.

For ground surveys, the prospector commonly walks while listening to the counts on earphones or watching the dial of the counter. Radioactive deposits may produce readings that are 10 to 100 times as great as "background" readings. If the deposits are covered by even a few tens of inches of overburden, however, the radiation cannot be detected. When a portable counter is used, the information should be interpreted with caution until it is verified by adequate sampling and chemical analysis.

Exploration for uranium has changed markedly over the past half century. The simple ionization chambers and Geiger counters of the 1940's have been superseded by sophisticated spectrometers or great reliability and sensitivity that are capable of discrimination among uranium, thorium, and potassium.

Research on the movements of radon, helium, and other daughter products of uranium has produced new or improved tools and methods to detect concealed uranium deposits. Radon gas, for example, can be detected in soils by use of portable radon counters or by radon cups containing radiation-sensitive film. 


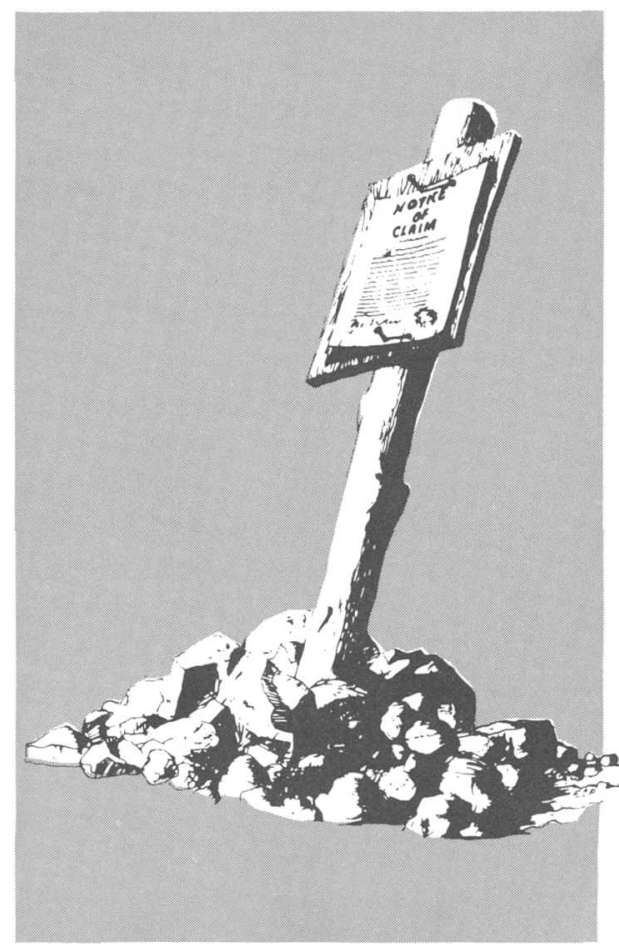

Claim to Mineral

Discovery and Exploration

Any U.S. citizen or any person who has declared an intention to become a citizen may locate a mining claim on public lands, which are mainly in the Western States. Although minerals are classified for purposes of mineral laws as locatable, leasable, or salable, only locatable mineral deposits can be staked and claimed under the General Mining Law of 1872. Locatable materials include metallic minerals (gold, silver, lead, and others) and nonmetallic minerals (fluorspar, asbestos, mica, and others).
All minerals on certain public lands, such as acquired lands (lands in Federal ownership obtained by the Federal Government by purchase, condemnation, gift, or exchange) and areas offshore, are subject to special leasing laws and regulations. Further, the location of mining claims is prohibited on some public lands. Regulations governing operations on mining claims apply to most public-domain lands in the national forests and the land administered by the Bureau of Land Management. The regulations appear in Parts 9 and 228 of Title 36, and Part 3809 of Title 43, of the Code of Federal Regulations.

A mining claim can be validly located and held only after a valuable mineral deposit has been discovered. The Department has established-and the courts have followed-the "prudent man" test to determine what constitutes discovery of a valuable mineral, (Chrisman v. Miller, 197 US 313(1905).) The Secretary, in Castle v. Womble, 19 Land Decisions 455,457 (1894), defined the test as, "Where minerals have been found and the evidence is of such a character that a person of ordinary prudence would be justified in further expenditure of his labor and means, with a reasonable prospect of success in developing a valuable mine then the requirements of the law have been met." Environmental factors and economic costs are important considerations in applying this test. In 1968, the U.S. Supreme Court in United Sates v. Coleman, 390 U.S. 599 (1968), approved the marketability test (that one must mine and 
market a mineral at a profit). In 1983, the Department of the Interior adopted the position that only a reasonable prospect of success in marketing, not guaranteed profitability, was the proper marketability standard (Interior Regulations Pacific Coast Molybdenum, 90 ID 352(1983).

Although the number of claims that can be held is unlimited, an actual physical discovery on each and every mining claim on public land must be made. Traces, minor indications, geological inference, or hope of a future discovery are not sufficient to satisfy the "prudent man" test. Making minor improvements, posting a notice, or performing annual assessment work will not create or perpetuate a right or interest in the land if there are no valuable minerals within the claim. (See Bureau of Land Management leaflet, "Staking a mining claim on Federal lands.")

Federal mining regulations pertaining to the acquisition of mineral rights on public land are administered by the Bureau of Land Management. For answers to questions on how and where prospecting is allowed on public lands, and to secure copies of their publications listed in the reference section at the end of this booklet, write to:

Office of Information

Bureau of Land Management (130) Washington, D.C. 20240

That office can also provide addresses of their regional offices in the Western States.

On privately owned land, the mineral rights must be obtained from the owner, generally through purchase or lease. State geologists and officials at county courthouses are other sources of information pertaining to the acquisition of mineral rights on public or privately owned land.

The prospector who succeeds in making a mineral discovery must consider how to explore the deposit in order to estimate its size and grade. Evaluating the economic potential of a deposit is sometimes difficult and may require the prospector to hire an experienced mining engineer. Estimates of the length, width, and depth of a deposit are needed to determine the tonnage of mineralized material present, and samples must be obtained for analysis to determine the grade of the deposit. Such samples must be representative of all the material that might be mined as ore, not just selected parts. For a review of sampling methods, see "Exploration and Mining Geology" (second edition) by Peters (1987), chapter 16.

\section{Services Available to Prospectors}

The U.S. Geological Survey does not identify, analyze, or assay samples of rocks, minerals, or ores at the request of individuals or corporations. Some State geological surveys will identify the minerals in ore samples submitted by residents of their State. These State agencies can also furnish helpful information on State mining laws and the geology of specific areas within the State. 
The Bureau of Mines, U.S. Department of the Interior, publishes the results of research on mining, milling, and metallurgy. The Bureau occasionally makes mineralogical examinations of mineral specimens submitted by individuals to help determine the mineral content, general characteristics, and potential economic importance of a deposit of which the sample is representative. The Bureau does not perform chemical constituent analyses of mineral samples submitted by the public because this service is available from commercial assay laboratories (see the Yellow Pages of the Telephone Directory under the heading "Laboratories,
Testing", or "Assaying"). The Bureau may limit the number of samples it will examine for an individual. Further information about this service may be obtained by writing to:

\section{Assistant Director, Metallurgy \\ U.S. Bureau of Mines \\ 2401 E Street NW \\ Washington, D.C. 20241}

Commercial laboratories or assay offices will perform chemical constituent analyses of samples. A comprehensive list of U.S. commercial laboratories can be found in the American Society for Testing and Materials (ASTM) Special Technical Publication 333-F, "Directory of Testing Laboratories," (1988).

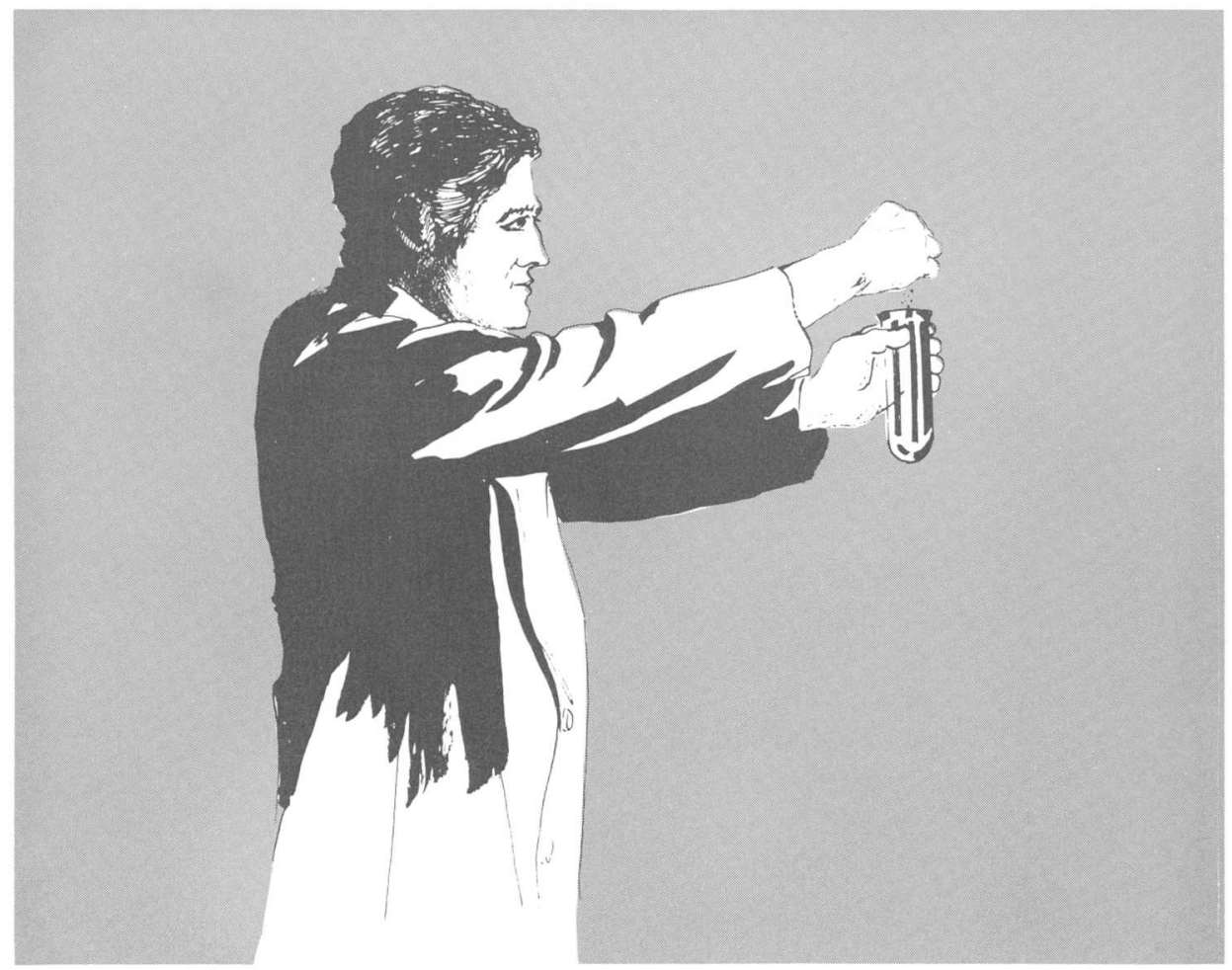




\section{Maps}

The U.S. Geological Survey (USGS) publishes many maps, in addition to those contained in their book reports, that are useful in prospecting. Among them are geologic maps which show rock types, areal distribution, geologic structures and mineral deposits; and topographic maps, which show the character and relief of land features by means of contour lines. To guide users to the maps they need, the USGS publishes geologic map indexes and indexes to topographic mapping for every State.

USGS maps and other publications may be examined at many large public and university libraries. Descriptions of these maps and ordering instructions can be found in USGS catalogs of publications.

Topographic map indexes showing published maps for all areas in the United States are available free upon request from:

Map Distribution Section

U.S. Geological Survey

Box 25286, Federal Center

Denver, CO 80225.

Geologic map indexes and book reports are available from:

Books and Open-File Reports Section

U.S. Geological Survey

Box 25425, Federal Center

Denver, CO 80225.

Residents of Alaska may request Alaska indexes directly from:

Alaska Distribution Section

U.S. Geological Survey

New Federal Building-Box 12

101 Twelfth Avenue

Fairbanks, AK 99701.
These indexes also list special maps, addresses of local map reference libraries, local map dealers, and Federal map distribution centers. An order blank showing prices and giving detailed instructions for ordering maps is included with each index.

Map indexes can also be obtained from Public Inquiries Offices which sell USGS publications and maps pertinent to their particular region on an over-the-counter-only basis. The locations of these Offices are as follows:

\section{ALASKA}

Room 101 4230 University Drive Anchorage, AK 99508-4664

E-146 Federal Building, Box 53 701 C Street

Anchorage, AK 99513

\section{CALIFORNIA}

7638 Federal Building

300 North Los Angeles Street

Los Angeles, CA 90012

Building 3, Room 3128

Mail Stop 533

345 Middlefield Road

Menlo Park, CA 94025

504 Custom House

555 Battery Street

San Francisco, CA 94111

COLORADO

169 Federal Building

1961 Stout Street

Denver, CO 80294 
DISTRICT OF COLUMBIA

Department of Interior Building

18th and C Streets, N.W.

Room 2650

Washington, DC 20240

\section{UTAH}

8105 Federal Building

125 South State Street

Salt Lake City, UT 84138

VIRGINIA

503 National Center

Room 1-C-402

12201 Sunrise Valley Drive

Reston, VA 22092

WASHINGTON

678 U.S. Courthouse

West 920 Riverside Avenue

Spokane, WA 99201

The U.S. Geological Survey has published a series of Mineral Investigations Resource (MR) maps which show the principal source areas of most commercial metals and minerals in the conterminous United States. These maps do not show mines and quarries but do show, by symbols, major mining districts of specific mineral commodities. A brief text accompanying each map describes the distribution and geology of the mineral commodity and contains a locality index keyed to the map and a bibliography. Mineral province maps (U.S. Geological Survey Open-File Report 79-576 series) show, for separate commodities, areas of present mining activity, within the 48 conterminous States past production, indication or expectation of undiscovered minable minerals, and (or) reported but possibly not fully evaluated mineral occurrences. The user of the MR or mineral province maps should have access to a large reference library so that pertinent references cited in each map's bibliography can be consulted.

Data compiled from aeromagnetic surveys of various areas have been published by the U.S. Geological Survey as Geophysical Investigations (GP) maps. These have lines connecting points of equal value of magnetic intensity overprinted on sheets showing cultural features; some maps also show the geology, and thereby facilitate the correlation of magnetic anomalies with geologic features.

For lists of MR, mineral province, and GP maps, write to:

Geologic Inquiries Group

$\cup \mathrm{S}$. Geological Survey

907 National Center

Reston, VA 22092

Results of aerial-radioactivity surveys conducted by the U.S. Geological Survey have been released as published maps or as open-file reports. These maps are listed in the catalogs of publications of the Geological Survey.

Aerial photographs for most parts of the United States are available from many government agencies at nominal cost. Information concerning the availability of conventional aerial photographs for any locality can be obtained from the:

National Cartographic Information Center

U.S. Geological Survey

507 National Center

Reston, VA 22092 
Information on satellite imagery and aerial and space photography can be obtained from the National Cartographic Information Center, above, or from:

EROS Data Center

U.S. Geological Survey

Sioux Falls, SD 57198

Radioactivity surveys of the United States were conducted in the 1970's by the Department of Energy in their comprehensive National Uranium Resources Evaluation (NURE) program. The NURE program included other types of geologic and related investigations implemented largely under contraci with various companies, universities, and laboratories. NURE reports can be obtained from:

Books and Open-File Reports Section

U.S. Geological Survey

Box 25425, Federal Center

Denver, CO 80225

NURE information is also found in U.S. Geological Survey Circular 994, "Uranium Resource Assessment by the Geological SurveyMethodology and Plan to Update the National Resource Base" (Finch and McCammon, 1987).

\section{References and Selected Readings}

Many of the following references can be consulted at large public or university libraries. Small libraries can arrange to borrow references on interlibrary loan from Federal depository libraries.

Baedecker, P.A., ed., 1987, Methods for geochemical analysis: U.S. Geological Survey Bulletin 1770A-K, variously paged.

Bateman, A.M., 1981, Economic mineral deposits (3d ed.): New York, Wiley, 593 p. Boyle, R.W., 1968, The geochemistry of silver and its deposits: Geological Survey of Canada, Bulletin 160, 264 p.

_ 1979, The geochemistry of gold and its deposits: Geological Survey of Canada, Bulletin 280, $584 \mathrm{p}$.

Brooks, R.R., 1983, Geobotany and biogeochemistry in mineral exploration: New York, Harper and Row, $322 \mathrm{p}$.

Bureau of Land Management, 1982, Patenting a mining claim on federal lands: BLM Leaflet, $12 \mathrm{p}$.

_ 1971, Regulations pertaining to mining claims under the general mining laws of 1872: BLM Circular 2289, $31 \mathrm{p}$.

1982, Regulations for staking of mining claims: BLM Circular 2516A, 11 p.

_ 1982, Surface management of public lands under the U.S. mining laws: BLM Circular 2480 A, 17 p.

1985, Staking a mining claim on federal lands: BLM Leaflet, $18 \mathrm{p}$.

Bureau of Mines, 1986, Mineral facts and problems, 1985 edition: Bureau of Mines Bulletin 675, $956 \mathrm{p}$.

_ 1988, Minerals yearbook, 1986, v. 1: Bureau of Mines, 1067 p.

Carlisle, Donald, and others, eds., 1986, Mineral exploration-biological systems and organic matter: Englewood Cliffs, New Jersey, Prentice-Hall (Rubey Volume V), $456 \mathrm{p}$. 
Chaussier, J.B., and Morer, Jean, 1987, Mineral prospecting manual: New York, Elsevier, $273 \mathrm{p}$.

Compton, R.R., 1985, Geology in the field: New York, Wiley, 398 p.

Cremer, M.J., and others, 1984, Chemical methods for analysis of rocks and minerals: U.S. Geological Survey Open-File Report 84-565, 153 p.

Curtin, G.C., and others, 1971, Utilization of mull (forest humus layer) in geochemical exploration in the Empire District, Clear Creek County, Colorado: U.S. Geological Survey Bulletin 1278-B, 39 p.

Dobrin, M.B., and Savit, C.H., 1988, Introduction to geophysical prospecting (4th ed.): New York, McGraw-Hill, 704 p.

Dodd, Kurt, and others, compilers, 1986, Guide to obtaining USGS information: U.S. Geological Survey Circular 900, 34 p.

Durrance, E.M., 1987, Radioactivity in geology-principles and applications: New York, Wiley, $441 \mathrm{p}$.

Erdman, J.A., and Olson, J.C., 1985, The use of plants in prospecting for precious metals, principally gold-a selected reference list and topic index: U.S. Geological Survey Open-File Report 85-118, 19 p.

Finch, W.I., and McCammon, R.B., 1987, Uranium resource assessment by the Geological Survey-methodology and plan to update the national resource base: U.S. Geological Survey Circular 994, $31 \mathrm{p}$.

Guilbert, J.M., and Park, C.F., Jr., 1985, The geology of ore deposits: New York, Freeman, $985 \mathrm{p}$.

Haffty, Joseph, and others, 1977, A manual of fire assaying and determination of the noble metals in geologic materials: U.S. Geological Survey Bulletin 1445, $58 \mathrm{p}$.

Haskins, Roger, and others, 1984, Handbook for mineral examiners: BLM Manual $\mathrm{H}-3890-1,120 \mathrm{p}$.

Heady, H.H., and Broadhead, K.G., 1976, Assaying ores, concentrates, and bullion: Bureau of Mines Information Circular 8714r, $24 \mathrm{p}$.

Hood, P.J., ed., 1979, Geophysics and geochemistry in the search for metallic ores: Geological Survey of Canada, Economic Geology Report 31, 811 p.

Hord, R.M., 1986, Remote sensing methods and applications: New York, Wiley, $368 \mathrm{p}$.

Ingamells, C.O., and Pitard, F.F., 1986, Applied geochemical analysis: New York, Wiley, $733 \mathrm{p}$.

Kirschenbaum, Herbert, 1983, The classical chemical analysis of silicate rocks-the old and the new: U.S. Geological Survey Bulletin 1547, 55 p.

Kuzvart, Milos, and Bohmer, Miloslav, 1986, Prospecting and exploration of mineral deposits (2d ed.): New York, Elsevier, 508 p.

Lacy, W.C., ed., 1983 (a), Mining geology: Stroudsburg, Pennsylvania, Hutchinson Ross (Benchmark Papers in Geology 69), 466 p.

_ 1983 (b), Mineral exploration: Stroudsburg, Pennsylvania, Hutchinson Ross (Benchmark Papers in Geology 68), 433 p.

Levinson, A.A., 1980, Introduction to exploration geochemistry-the 1980 supplement (2d ed.): Wilmette, Illinois, Applied Publishing, $924 \mathrm{p}$.

O'Leary, R.M., and Meier, A.L., 1986, Analytical methods used in geochemical exploration, 1984: U.S. Geological Survey Circular 948, 48 p.

Pearl, R.M., 1973, Handbook for prospectors (5th ed.): New York, McGraw-Hill, $472 \mathrm{p}$. 
Peters, W.C., 1987, Exploration and mining geology (2d ed.): New York, Wiley, $720 \mathrm{p}$.

Rose, A.W., and others, 1979, Geochemistry in mineral exploration (2d ed.): New York, Academic Press, $657 \mathrm{p}$.

Stebbins, S.A., 1987, Cost estimation handbook for small placer mines: Bureau of Mines Information Circular 9170, $94 \mathrm{p}$.

Stout, K.S., 1984, The profitab!e small mine-Prospecting to operation: New York, McGraw-Hill, $174 \mathrm{p}$.

Thrush, P.W., and Staff of the Bureau of Mines, 1968, A dictionary of mining, mineral, and related terms: Bureau of Mines, $1269 \mathrm{p}$. Out of print.

Van Blaricom, R., ed., 1980, Practical geophysics for the exploration geologist: Spokane, Washington, Northwest Mining Association, $303 \mathrm{p}$.

Ward, F.N., ed., 1975, New and refined methods of trace analysis useful in geochemical exploration: U.S. Geological Survey Bulletin 1408, 105 p. Out of print.

Ward, F.N., and others, 1963, Analytical methods used in geochemical exploration by the U.S. Geological Survey: U.S. Geological Survey Bulletin 1152; 100 p. Out of print.

Watterson, J.R., 1985, A procedure for estimating bacillus cereus in soil and stream-sediment samples-a potential exploration technique, in Journal of Geochemical Exploration, v. 23 no. 3, p. 243-252.

Wells, J.H., 1969, Placer examination-principles and practice: Bureau of Land Management Technical Bulletin 4, $155 \mathrm{p}$.

West, J.M., 1971, How to mine and prospect for placer gold: Bureau of Mines Information Circular 8517, $43 \mathrm{p}$.

\section{Additional readings}

Economic Geology, the Bulletin of the Society of Economic Geologists: published by Economic Geology Publishing Co., Box 74, Michigan Technological University, Houghton, MI 49931. Semiquarterly jounal ( 8 issues/year).

Engineering and Mining Journal: published by McGraw-Hill Publications Co., 1221 Avenue of the Americas, New York, NY 10020. Monthly.

The Leading Edge: published by the Society of Exploration Geophysicists, 8801 So. Yale, Tulsa, Oklahoma 74137. Monthly.

Mining Engineering: published by the Society of Mining Engineers, American Institute of Mining Engineers, 540 Arapeen Drive, Box 8800, Salt Lake City, UT 84108. Monthly.

Rocks and Minerals: published by Heldref Publications, 4000 Albemarle St., N.W., Washington, D.C. 20016. Monthly.

World Mining: published by World Mining, 500 Howard Street, San Francisco, CA 94105. 


\section{Directories}

ASTM Special Technical Publication 333-F, "Directory of Testing Laboratories," (1988), includes names and addresses of commercial laboratories and describes the range of services from each. Purchase from Americal Society for Testing and Materials, 1916 Race Street, Philadelphia, PA 19103.

"The Leading Edge" May issue includes names and addresses of firms offering geophysical services or instruments or both. Published annually. Purchase from the Society of Exploration Geophysicists, 8801 So. Yale, Tulsa, OK 74137.

"Mining Annual Review" summarizes worldwide developments in mining by commodity and by geographic area. Includes a directory to manufacturers and services for the mining industry. Published annually in June. Purchase from the Mining Journal, Ltd., 15 Wilson Street, London EC2M 2TR, England.

These directories may also be available in large reference libraries.

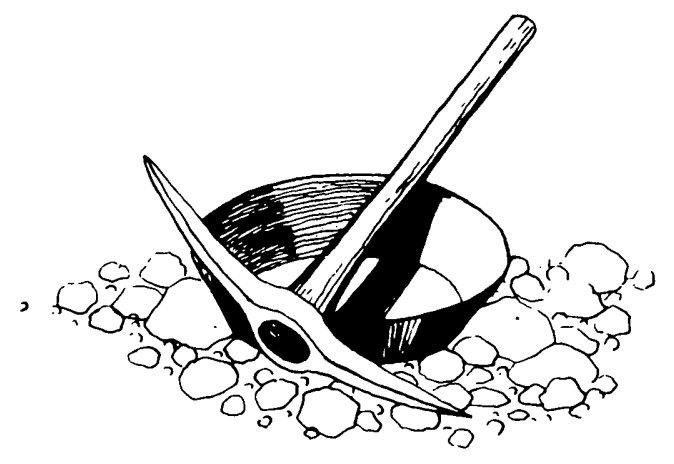

This publication is one of a series of general interest publications prepared by the U.S. Geological Survey to provide information about the earth sciences, natural resources, and the environment. To obtain a catalog of additional titles in the series "General Interest Publications of the U.S. Geological Survey," write:

Book and Open-File Reports Section

U.S. Geological Survey

Federal Center, Box 25425

Denver, CO 80225 
As the Nation's principal conservation agency, the Department of the Interior has responsibility for most of our nationally owned public lands and natural resources. This includes fostering the wisest use of our land and water resources, protecting our fish and wildlife,

preserving the environmental and cultural values of our national parks and historical places, and providing for the enjoyment of life through outdoor recreation. The Department assesses our energy and mineral resources and works to assure that their development is in the best interests of all our people. The Department also has a major responsibility for American Indian reservation communities and for people who live in Island Territories under U.S. administration. 